\title{
THE ENVIRONMENTAL APPROACH OF SLATINA CITY REGARDING WASTE MANAGEMENT
}

\author{
Dana-Maria Oprea ${ }^{1}$
}

ABSTRACT: This article is focused both on a general description and the actual process of waste management in the area of Slatina city. After the conceptual presentation, causes and classes of waste, the article develops and describes municipal and industrial waste around Slatina by also analyzing their temporal evolution. The main types of waste management are described by highlighting their advantages and disadvantages along with the principles on which proper waste management is based. The conclusion regards the effect of applying waste management and justifies the choice of this specific urban area.

Keywords: waste, management, environment, Slatina.

JEL Codes: Q50, Q52, Q57.

\section{Introduction}

Both urban and industrial development, as consequences of demographic expansion and increasing quality of life, along with the necessity of insuring permanently growing consumption needs, lead to diminishing and depletion of natural reserves of raw materials and fossil fuel. At the same time, a greater volume of daily activities' waste is being generated, enhancing the danger of polluting the environment. Due to the statements above, the article covers the problem of waste management and the actual process of collecting and handling waste by authorized institutions in the area of Slatina city.

\section{Literature review}

The European Economic Community developed a common policy regarding waste management beginning with 1975, which resulted in regulations and research and development programs. As a result, the Integrated Waste Management arose, concerning especially reducing waste volume, as well as optimizing their final disposal. Waste recycling is an applicable alternative to waste disposal for some decades now, having beneficial effects in various countries. Nowadays, in Romania, waste management has its difficulties because of insufficient funds and lack of both institutional organizing and international long-term contracts for acknowledging, assimilation and modern implementation of handling waste. Unexploited waste comes as precarious technical and technological levels in the domain. In order to observe the environmental aspect under a larger perspective, the article depicts actual facets of waste management in the area of Slatina city.

\section{General aspects. Definitions, causes, classification}

In literature, the term waste appears under several denominations: urban solid waste, industrial waste, organic or inorganic waste, household waste, street waste, household trash, refuses, etc.

Waste is any unwanted or useless material or object, without any transformation.

\footnotetext{
${ }^{1}$ Artifex University, Bucharest, Romania, e-mail: danamartines@yahoo.com
} 
In French legislation, it is "considered final, last, waste resulted from treating other waste, impossible to transform in actual technical and economic conditions, especially by extracting its useful part or by reducing its harmful behavior".

Generally speaking, waste is an irreversible consequence of human activities. The main causes of waste genesis are:

- biological (as the result of life cycles in vegetal, animal and human environment);

- chemical (all chemical reactions are governed by the principle of conserving substance, resulting in a final useful product, plus useless elements);

- technological (resulted from processing and transforming raw materials);

- economic (all products have limited physical life);

- commercial (the attractiveness of new products removes old products from the market, packaging often having an important role in marketing); natural risks);

- accidental (malfunctions of production systems as well as technological and major

- ecological (unfortunately, even depollution activities generate waste).

Despite having such a large range of waste, the most commonly invoked is solid waste. To treat the subject under the light of reality, the following paragraphs develop the criteria that classify waste. reject or residue.

By destination, waste can be: recoverable or irretrievable. As by its origin, it can be:

By chemical approach, waste can be: organic or inorganic. As by characteristics of main constituents, it can be: combustible (paper, plastics, wood etc.), fermentable (food waste, vegetables, fruits), inert (ceramic, metals, glass) or fine (slag, soil, ash).

Of all these classes of waste, the most important regarding environmental impact (especially the urban aspect) is municipal and industrial waste, both being solid waste.

\section{Municipal and industrial waste in the area of Slatina city}

Municipal waste is the total amount of household waste generated by the population in cities and villages, institutions and commercial units, plus street waste collected in public bins, construction waste and demolishing waste including mud resulted from wastewater treatment plants in urban areas.

Waste management includes structured or unstructured collection of waste in public bins, sanitation of public spaces where the waste diffuses because of educational causes or lack of a modern deposing infrastructure and handling by burning or recycling.

Every person generates an approximate quantity of $3 \mathrm{~kg}$ of household waste per day. Only $1.7 \mathrm{~kg}$ is collected by the municipality, the rest of it being transformed by other means (for example, burning in houses).

In Romania, as in many other countries, municipal waste cannot be quantified due to lack of a coherent collecting system. Given the fact that the average quantity per capita was estimated to $400 \mathrm{~kg}$ in 2006, this system becomes a problem of human ecosystems: at least 3 millions of tones of waste get back to the actual living environment.

In Slatina, there are eight selective points for collecting waste for paper, plastic, glass, metal and compostable.

They may say that the level of economic and cultural development of a geographical area can be quantified by the way the community manages to resolve the problem of waste.

The municipal waste deposit in Slatina was opened back in 1990, having a total projected surface of 4 ha and a projected capacity of $1020000 \mathrm{~m}^{3}$, with the ceasing term established for 2007, being considered "b"-class. The handling is managed by S.C. SALUBRIS S.A., annually deposing an average quantity of $125037 \mathrm{~m}^{3}$. 
Not because of its composition and characteristics - as the figure below shows (fig. no. 1), but because of the high costs implied, waste incineration does not happen too often. In Romania, incineration points are found in Bucharest, Iaşi and Constanţa.

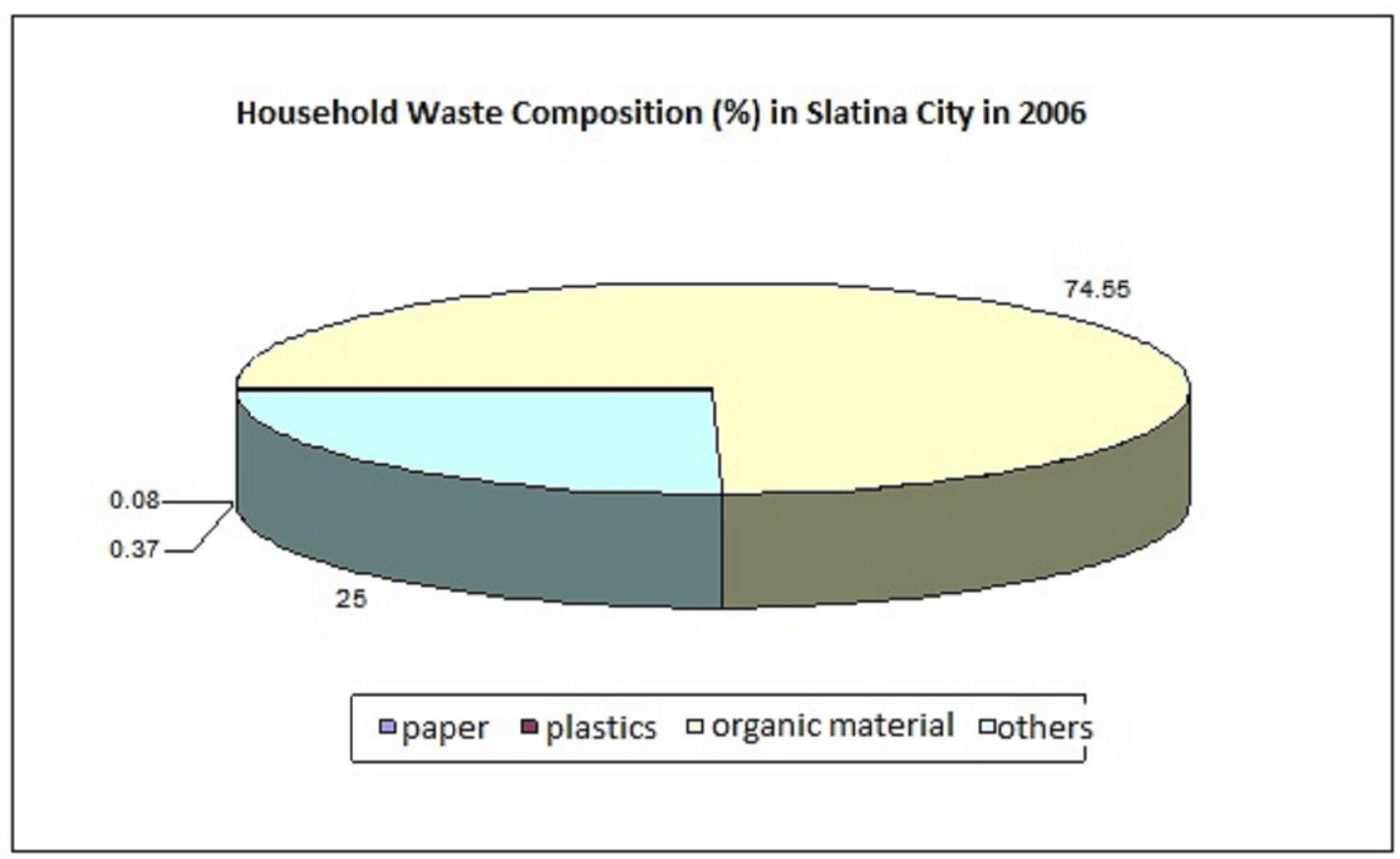

Processed data from APM Olt, 2007.

Figure no. 1 - Household waste composition in Slatina city in 2006 (\%)

On the basis of the data in the figure above, it can be stated that organic waste is in majority, followed by paper waste. Also, it is clearly that glass waste, metal waste and textile waste are missing. In comparison to household waste in immediate neighborhood of the city, the composition of waste differs with the majority of animal waste (straws, leaves, roots and animal dejection), whilst paper waste, plastics and others are extremely reduced as percentage.

Organic materials, especially food waste, in anaerobic environments and high temperatures (in summer) are exposed to putrefaction, generating toxic substances (amines, cyanic compounds), emanating unpleasant odours which, in ecological conditions of depositing, based on biological principles, may fortunately generate gases and natural fertilizer. If unauthorizely incinerated by local people living in individual houses, waste may liberate in the atmosphere carbon oxides, sulfur oxides and nitrogen oxides, as well as soot and hydrocyanic acid through used rubber and plastic material burning.

Industrial waste includes pieces left after the extraction and processing in mines and plants. The amount of waste is 40 times greater than municipal waste together with manufacturing waste.

The main categories of industrial waste are: mine tailings, soot and slag from thermals, metallurgical waste, residual mud and chemical waste. Economic activities that may generate such waste are extractive, metallurgical and chemical industries, manufacturing and food industry, energy production, petroleum refining and animal husbandry agriculture.

Waste deposing on uncovered terrain is the most important way of removing industrial waste in Romania, more than $80 \%$ of all waste being deposited every year. Most of industrial waste (76\%) is placed on relatively narrow areas, usually simple concrete platforms, only $60 \%$ of it being placed outside cities.

Ways of collecting, transporting and deposing municipal and industrial waste (generally all kinds of waste: coming from production, hospitals, dangerous waste, radioactive or mud waste, etc.) have a negative impact on environmental factors, health and quality of life, because toxic 
substances, metals like lead, mercury or cadmium, pesticides, solvents or petroleum products may be found in their composition. Incorrect deposition may also affect soil, and by infiltration, they may reach both underground and surface waters by soluble substances. On the other hand, the air becomes polluted by dust particles produced during waste handling or gases diffused during waste decomposition fermentation.

As a result, administrative, financial and ecological waste management has been imposed.

\section{Waste management in the area of Slatina city}

Waste management is the total amount of collecting, transporting, treating, recycling and deposing operations regarding waste. Generally speaking, waste management refers to reducing the harmful effect of residual materials resulted from daily human activities over people's health, environment or habitat appearance.

Waste management has a double target:

- optimal integration of waste, starting with the essential objective - protection of the environment neutralizing its negative effects;

- $\quad$ maximum conservation of exhaustible resources.

Resolving the problem of waste is a challenge, and the most modern method to accomplish it is integrated management of waste, which consists of firstly diminishing the waste right from the source and secondly applying a series of processes that imply reusing, treating, burning, etc. that come with both advantages and disadvantages depicted in the table below.

Reducing waste is based on reducing consumption, refusing unnecessary products, reintegration of waste, reuse and recycling.

Additional management in reducing waste implies burning in incinerators in order to produce electricity or heat, storing or burying waste in the lithosphere, having again its specific advantages and disadvantages (table no. 1).

Table no. 1.

\section{Advantages and disadvantages of the main types of waste management}

\begin{tabular}{|c|c|c|}
\hline Management type & Advantages & Disadvantages \\
\hline Recycling & $\begin{array}{l}\text { Diminishes environmental pollution } \\
\text { Ensures biodiversity } \\
\text { Diminishes raw materials consumption } \\
\text { Economy in energy and finances }\end{array}$ & $\begin{array}{l}\text { Diminishes profit from other types of } \\
\text { management } \\
\text { Difficulties in collecting and sorting } \\
\text { Reduced capacity of reusing } \\
\text { Does not eliminate burning or deposing }\end{array}$ \\
\hline Burning & $\begin{array}{c}\text { Eliminates pollution of soil and water } \\
\text { Eliminates waste storing } \\
\text { Generates low price energy } \\
\text { Metals can be recovered }\end{array}$ & $\begin{array}{c}\text { High costs for buildings } \\
\text { Pollutes atmosphere } \\
\text { Diminishes recycling } \\
\text { Adverse reactions regarding localization }\end{array}$ \\
\hline $\begin{array}{c}\text { Ecological areas } \\
\text { deposing }\end{array}$ & $\begin{array}{l}\text { Large capacity and fast construction } \\
\text { Reduced pollution of waters } \\
\text { Reusing terrains after filled }\end{array}$ & $\begin{array}{c}\text { Pollutes air and underground waters } \\
\text { Discourages recycling } \\
\text { Large traffic }\end{array}$ \\
\hline
\end{tabular}

In populated area, waste collection may have unstructured locations, so that after being deposed, processing and structured collection comes next by directly integrating the recycling and deposing phase.

Optimal waste management implies a series of measures, actions and activities available through legal and administrative levers, financially sustained on the long term.

Romania's environmental policy is based on a series of principles according to European and international regulations, ensuring protection and conservation of nature, biological diversity and durable use of its components.

The main principles set at the basis of waste management activities are: 
- $\quad$ the principle of preliminary measurements, correlated to the principle of BATNEEC use (Best Available Technology Not Entailing Excessive Cost), states that any activity (including waste management) must take into account queries for environment protection, current state of technology development, choosing and applying feasible economic measures;

- the principle of protection of raw materials included in the "sustainable development" concept states the necessity of diminishing and efficiently using of raw materials, especially of the non-regenerative ones, emphasizing the use of secondary raw materials.

- the principle of prevention states the hierarchy of waste management activities, in descending order of their importance: avoiding their apparition, minimizing quantities, recovering or eliminating waste in safe conditions regarding the environment;

- $\quad$ the principle of the paying polluter, correlated to the principle of the responsible producer and consumer, states the necessity of adequate economic regulations;

- $\quad$ the principle of proximity, correlated to the principle of autonomy, states that waste must be treated and eliminated as much as possible on national territory and as close as possible to their source; the export of dangerous waste may occur as long as receiving countries dispose of adequate technologies that respect queries regarding international waste trade;

- $\quad$ the principle of substitution refers to the importance of substitution of dangerous raw materials with safe raw materials, thus avoiding the possibility of generating dangerous waste;

- $\quad$ the principle of subsidiary waste states that competent decisions regarding waste management must be taken at the lowest administrative level possible, and must be based on common criteria regionally and nationally established;

- $\quad$ the principle of integration states that waste management activities are part of social and economic activities that may generate them.

In Romania, waste management is founded on O.U.G. 78/2000, modified and supplemented by O.U.G. 61/2006, approved, modified and supplemented by law no. 27/2007, which implements a series of directives according to the European Council. In Romania, the National Agency for Environment Protection, along with the Ministry of Environment, is responsible for the coordination of this activity.

Lately, in Slatina has been recorded a diminish in waste volume due to decrease in production together with economic agents' efforts as to reduce waste, knowing the fact that the most efficient solution for protecting environment is cutting volume of waste right from the source.

Greater economic units that generate large amounts of waste in Slatina are S.C. ALRO S.A. Slatina, S.C. ALPROM S.A. Slatina, S.C. ELECTROCARBON S.A. Slatina and S.C. ARTROM S.A. Slatina. Most of their waste is dangerous and unstructured.

Deposits of dangerous waste are:

- S.C. ALRO S.A. Slatina - aluminium industrial waste (slags);

- $\quad$ S.C. UTALIM S.A. Slatina - slimes from treatment of metallic surfaces;

- $\quad$ S.C. ARTROM S.A. Slatina - slimes from treatment of metallic surfaces.

In 2005 and 2006, in the area of Slatina city were produced the following quantities of waste as depicted in the table below, recording a decrease in the amount of used batteries, an increase in the amount of used oil, petroleum slim and chemical waste, as well as a constant amount of hospital waste (table no. 2 and table no. 3 ).

Table no. 2 .

Types of dangerous waste recorded in the area of Slatina city in 2005

\begin{tabular}{|c|c|c|c|}
\hline Type of waste & Collected quantity $(\mathrm{t})$ & Revalued quantity(t) & Stored quantity(t) \\
\hline Used oil & 311 & 299 & 12 \\
\hline Used batteries & 190 & 178 & 12 \\
\hline Hospital waste & 132 & 132 & 0 \\
\hline Petroleum slim & 118 & 0 & 118 \\
\hline Chemical waste & 14 & 9 & 5 \\
\hline
\end{tabular}


Processed data from APM Olt, 2007.

Table no. 3 .

Types of dangerous waste recorded in the area of Slatina city in 2006

\begin{tabular}{|c|c|c|c|}
\hline Type of waste & Collected quantity(t) & Revalued quantity(t) & Stored quantity(t) \\
\hline Used oil & 323 & 311 & 12 \\
\hline Used batteries & 95 & 90 & 5 \\
\hline Hospital waste & 132 & 132 & 0 \\
\hline Petroleum slim & 10500 & 0 & 10500 \\
\hline Chemical waste & 15 & 14 & 1 \\
\hline
\end{tabular}

Processed data from APM Olt, 2007.

Deposing industrial waste is individual to every industrial level, as follows:

- $\quad$ S.C. ALRO S.A. Slatina - ecological deposit;

- $\quad$ S.C. ELECTROCARBON S.A. Slatina - unstructured deposit;

- $\quad$ S.C. ALPROM S.A. Slatina - unstructured deposit;

- $\quad$ S.C. ARTROM S.A. Slatina - structured deposit.

\section{Conclusions}

Nowadays, common environment is dynamic, and every opportunity of increasing profit must be taken into account beginning with efficiency in operational steps of the production process, to reducing capital costs through simple rather than complex solutions. Thus, an example of economic and environmental efficiency is waste management largely developed in this article under both general aspects - definitions, classification, principles, advantages and disadvantages of the main types of waste management, and specific aspects as applied and highlighted in the area of Slatina city. It is not by chance that the article treats this particular area, the main argument being that Slatina is the most important centre in aluminium industry in the entire country, being a middle-sized city (municipal waste).

As shown in the above data processing, whose source is the Environmental Protection Agency Olt County, the most important undertaking and thus the largest polluter of urban, S.C. ALRO S.A. has arranged environmentally hazardous landfill, ascertaining the amount of industrial waste reduction since 2005 and the predominance of organic waste in municipal waste structure.

Concluding, waste management is already highly applied in Slatina and its surroundings, but further decisions and implementation are necessary in order to actually improve waste handling.

The above approach of the article is a starting point for reaching substantial improvement through a broader analyzing perspective of the environmental problem arose by generating and managing of waste on the whole as well as particularly.

\section{References}

1. Bold O.V., Mărăcineanu G.A., 2003. Urban and industrial solid waste management, Matrix Rom Publishing House, Bucharest

2. Matei E., 2007. Human ecosystems, Universitara Publishing House, Bucharest

3. Munteanu I.O., 2007. Ecology and environmental protection, Universitas Publishing House, Deva

4. www.mmediu.ro, 2011

5. www.anpmot.ro, 2011 